\title{
Den performativa blicken
}

Peter Gillgren

Elif Shafaks roman The Gaze (Blicken) handlar om ett omaka kärlekspar i Istanbul. Hon är oerhört stor och har ett groteskt utseende, han är väldigt småväxt och helt skallig. De ses ogärna ute tillsammans utan håller sig mest för sig själva, bortom allas blickar. Kvinnan hade, påpekar Shafak, "inte varit så ful om hon inte hade blivit sedd". . Ibland när de går ut tillsammans målar de sig, han med smink och hon med en mustasch. Det kan vara ett sätt att avvärja blickarna, tänker de, men istället slutar det inte sällan med att de framåt småtimmarna råkar i slagsmål på någon skum krog. Mannen börjar samla på blickar, som noteras och klassificeras i ett arkiv. Men det är inte heller till någon hjälp. Historien slutar sorgligt.

Det är blickar som gör de här människorna till vad de är eller blir. Om en annan kvinna i romanen heter det å andra sidan "att hon inte hade varit så vacker", om hon i sin tur inte hade blivit sedd. Blickar kan få oss att känna uppskattning eller kritik, beundran eller förakt. Inom psykologin och existentialismen spelar blickar en viktig roll, det är 'den andres blick' som bekräftar och formar oss människor. ${ }^{2}$ Genom andras ögon lär vi känna oss

Hur du refererar till det här kapitlet:

Gillgren, P. 20I7. Den performativa blicken. I Hayden, M. H. and Snickare, M. (red.) Performativitet: Teoretiska tillämpningar i konstvetenskap: I. Pp. 62-79. Stockholm: Stockholm University Press. DOI: https://doi.org/Io.I6993/bal.e. License: CC-BY 4.0 
själva. Blickar är performativa. De inte bara registrerar verkligheten utan formar och förändrar den i hög grad.

I bildkonsten är blickar i hög grad aktiva agenter. Det gäller blickar som fälls, möts och agerar inne i bilderna, i det estetiska rummet. Men också blickar som rör sig i det reella rummet, utanför och kring konstverken. Spelet mellan det estetiska

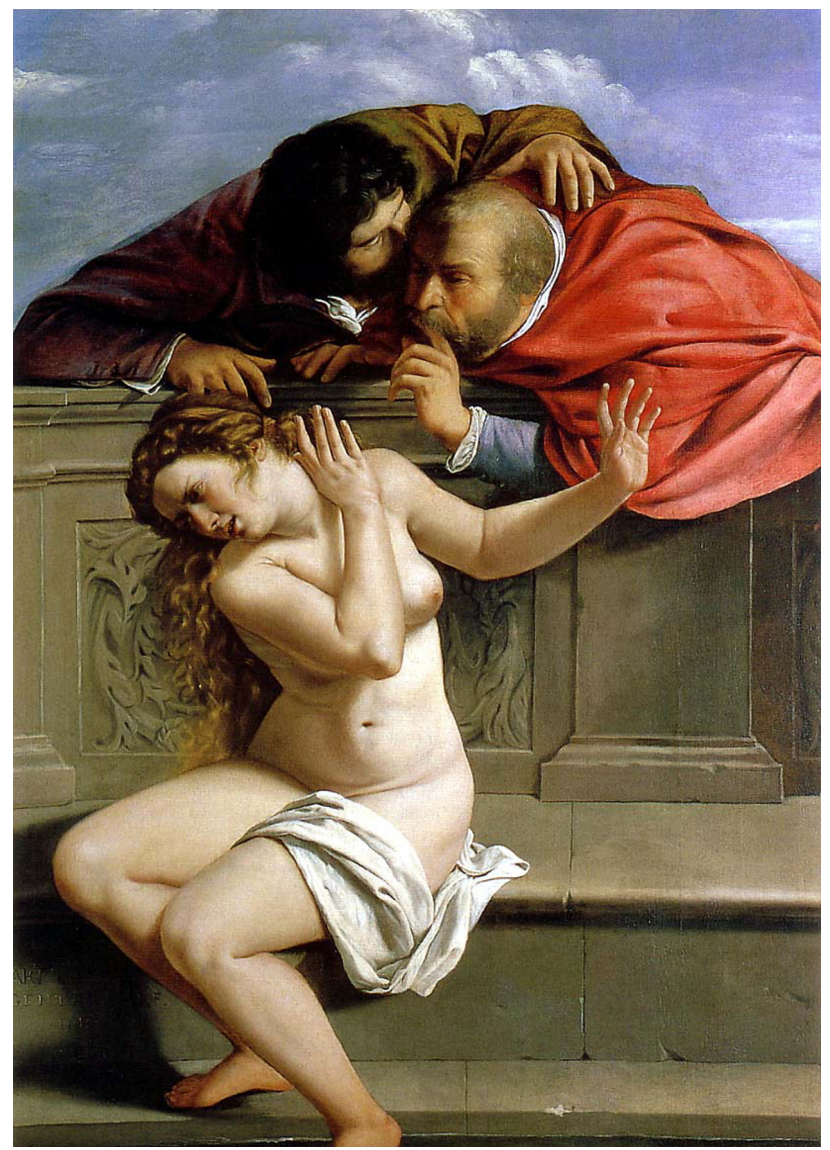

Bild 8. Artemisia Gentileschi, Susanna i Badet, I6ro. Olja på duk. I70 × I $9 \mathrm{~cm}$. Schloss Weißenstein, Pommersfelden (Tyskland). Källa: Wikimedia Commons (Copyright CC-o, Public Domain) 
och det reella rummet handlar i hög grad om hur blickar formuleras, manipuleras och möts i intrikata samspel. ${ }^{3}$

Artemisia Gentileschis målning Susanna $i$ Badet är en av konstnärens tidigaste målningar, tillkommen I6IO när hon bara var I7 år gammal (bild 8).4 Historien är välkänd från Bibeln (Daniel I), men egentligen behöver vi inte känna till den särskilt väl för att förstå målningen. Susanna skall ta ett bad, men antastas av två äldre män. Gubbar. De hänger över henne som ett obehagligt mörkt moln mot den ljusblå bakgrunden, de viskar och intrigerar med varandra och bryr sig inte om hennes obehag eller avvisande gester. Men det är inte bara männen i bilden som stör henne, det är också konstbetraktarens blick. Susannas avvisande gest är riktad lika mycket mot oss som mot männen. Å ena sidan blottas hennes nakna kropp för betraktarens utforskande blick. A den andra sidan visar hon ett starkt obehag inför detta. Susannas kropp kränger sig i obehag, liksom blickarna kränger sig kring henne.

Målningen är komplex, genom att den både bekräftar och problematiserar det manliga betraktandet som norm och normalitet. Begreppet 'den manliga blicken' fick en definitiv bestämning av filmvetaren Laura Mulvey i en kort essä om I950-talets Hollywoodfilm. ${ }^{5}$ Mulvey menar att män och kvinnor spelar olika roller i de här filmerna och har olika betraktarfunktioner. Männen agerar och driver handlingen framåt, de står för filmens narrativa inslag. Kvinnorna är passiva och objekt för publikens estetiska kontemplation. Båda funktionerna är fullt relevanta inslag i en film, men de stereotypa 
könsrollerna inte bara representerar en viss könsmaktsordning utan är aktivt med och skapar denna. Hollywoodfilmer från I950-talet har alltså ett performativt anslag. De fostrar till ett visst strukturellt betingat betraktande och en viss patriarkal ideologi.

I Artemisias målning är Susannas kropp blek och vacker, idealiserad enligt klassiska konventioner. Hon är ett objekt för den kontemplativa blicken, hon möter aldrig betraktarens blick utan vi kan till synes ostörda betrakta henne. Betraktaren tilldelas tveklöst en subjektsposition. Men samtidigt visar Susanna på starkt obehag inför objektifieringen. Hon vill inte vara den vår blick gör henne till. På så sätt spelar hon inte Hollywoodrollen utan liknar mer den kvinnliga huvudpersonen i Shafaks roman. Hon ger öppet uttryck för sin vånda.

Vi kan även säga att det är betraktarens blick som gör hela den målade scenen till en bild av 'Susanna i badet'. Foten som doppas försiktigt i vattnet i bildens nederkant ger bara en liten antydan till ett badande. Det är betraktarens blick som läser av den som ett bad och som kopplar detta till berättelsen om Susanna. Den klassiska reliefen i bakgrunden förstås av blicken som en klassisk referens. Den förstärker intrycket av att Susannas kropp också den är klassisk, att hela bilden är en kommentar till en klassisk tradition av estetiska ideal och konventioner. Det finns en kylighet i färgskalan och miljön som är påtaglig och som ger betydelse åt bilden och åt Susannas obehag. Den här kvinnan är inte en del av naturen, hon är inte vatten, växter eller av djurvärlden. Den klassiska kyligheten förstärker intrycket att hon befinner sig i en urban, kulturell miljö där nakenheten är särskilt besvärande och onaturlig. 
Vi blickar vidare. Målningen vi ser på är gammal, tillkommen för flera hundra år sedan. Kanske var den tiden annorlunda och man såg inte på de här sakerna likadant som idag? Men en jämförelse med andra bilder som representerar Susanna i badet, till exempel av Tintoretto eller Veronese, förstärker intrycket av att den här bilden vill säga någonting annat och annorlunda, att den inte bara är ett uttryck för sin tid utan kanske redan på sin tid ville verka performativt och förändrande. Hos andra konstnärer skildras Susanna som obekymrad av våra blickar. Männen smyger sig på henne och visar sig bara för oss betraktare. Männen - liksom vi själva - tilllåts då ostört att se på henne utan att hon märker någonting, eller låtsas om vår närvaro. Susannas nakenhet skildras hos Tintoretto eller Veronese som mer naturlig, som en följd av kvinnans jordnära och av naturen givna karaktär, där nakenheten inte upplevs av betraktaren som lika störande och konstlad. Artemisias målning tycks som en kritisk kommentar till sådana, andra målningar och till den egna tidens patriarkala ordning.

Kanske är målningen annorlunda för att den är målad av en kvinna? Men vi vet inte mycket om hur Artemisia tänkte eller tyckte när hon utförde målningen. Många kvinnor delade sin tids patriarkala värderingar. En del män gjorde det inte. Eftersom Artemisia var så ung när målningen utfördes finns det flera konsthistoriker som tror att hennes far, som också var en berömd konstnär, var med och utförde målningen. Ibland har man velat dra paralleller mellan Artemisas måleri och den rättegång hon var indragen i, där fadern anklagade en annan konstnär för att ha våldtagit dottern. Men den händelsen 
ägde rum efter det att den här målningen utfördes, vilket gör att det är svårt att veta om den alls går tillbaka på några konkreta privat erfarenheter. ${ }^{6} \mathrm{Vad}$ vi däremot kan säga är att målningen spelar med och samtidigt undergräver den egna tidens - och andra tiders - konventioner kring kön och representation.

Vår egen blick kan tyckas performativ, som att den gör Susanna till den hon är. Det är sant. Men målningen är också en blick tillbaka mot oss. Den konstruerar oss som betraktare och får oss potentiellt att känna obehag inför den egna blicken mot bilden. Den implicerar ett visst betraktande. Ett implicit betraktande som målningen samtidigt deklarerar att den inte sympatiserar med. Begreppet implicit betraktare kommer från receptionsestetiken, som också förser oss med ytterligare några användbara begrepp i sammanhanget. 7 De två männen ovanför Susanna fokaliserar Susanna, det vill säga deras gester och blickar pekar ut henne som den centrala personen i sammanhanget. Samtidigt intar de en hotfull attityd gentemot henne. Som betraktare i det reella rummet tenderar vi att låta oss vägledas av sådana fokaliserande blickar och de bidrar till att inplantera en negativ, rent av destruktiv, relation mellan oss och huvudpersonen. Vare sig vi önskar det eller inte, tenderar vi att identifiera oss med de två männen, eftersom vi intar samma betraktande position i förhållande till centralmotivet.

Andra begrepp från receptionsestetiken är fragment och vakanser. Fragment är saker som är ryckta ur sitt sammanhang och därför förefaller oss som i särskilt behov av tolkning. Vakanser är hela scener som inte riktigt passar ihop utan behöver sammanfogas av betraktarens performativa blick. I Artemisia 
Gentileschis målning finns inte mycket sådant, även om skymten av vatten i nederkant kan sägas vara ett fragment som får oss att tolka målningen som en bild av Susanna i badet och relationen mellan männen och Susanna som skulle kunna beskrivas som vakant (i behov av att förklaras och fyllas ut). En målning av Quentin Matsys från I 5 I 4 innehåller betydligt tydligare sådana fragment och vakanser.

Stämningsläget är mycket mer stillsamt här än i Susannabilden och allt tycks till att börja med vara i bästa harmoni (bild 9). ${ }^{8}$ Två personer sitter vid ett

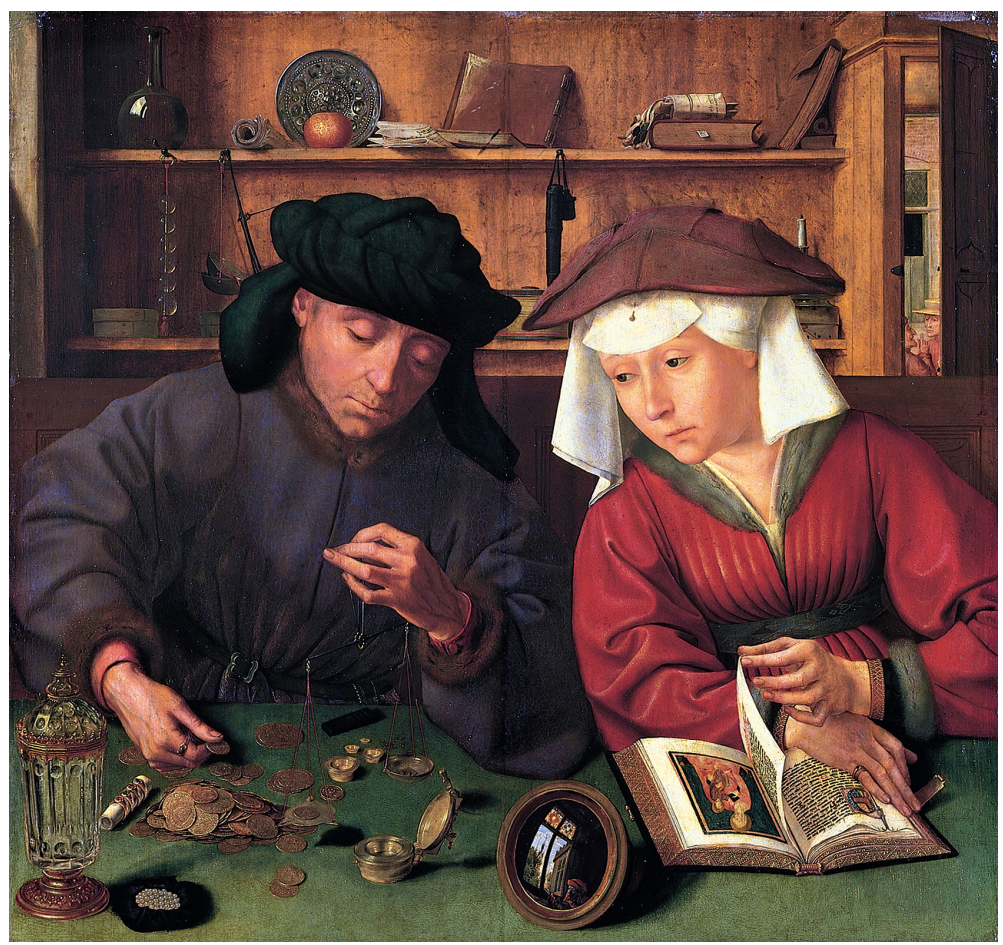

Bild 9. Quentin Matsys, Myntväxlarna, I 5 I 4. Olja på pannå. 7 I $\times 67 \mathrm{~cm}$. Louvren, Paris (Frankrike). Källa: Wikimedia Commons (Copyright CC-o, Public Domain) 
bord och studerar en ansamling av föremål och ting. Mannen har blicken stadigt riktad mot en liten våg, på vilken han väger upp mynt. Kvinnan bläddrar i en liten bok med bland annat en bild av Maria och Jesusbarnet. Men hennes blick är inte riktad mot boken utan mot mannens syssla. Målningen är inte stor, bara 5 I $\times 68 \mathrm{~cm}$. För att se alla detaljer behöver vi komma nära. Så nära att vår blick blir jämbördig med parets. Liksom dem kommer vi att med blicken utforska de många detaljerna i bilden. Vad betyder alla dessa ting, alla de föremål som paret tycks tillmäta sådan allvarsam betydelse? Hur för vi samman alla dessa fragment till en sammanhållen förståelse och begriplig mening?

De viktigaste föremålen verkar vara pengarna och deras vägande, det är mynten som de båda figurerna fokaliserar. Men vid närmre betraktande är det nog snarast själva vågen som är i fokus. Den är så starkt fokaliserad att man tenderar att läsa allt annat i bilden som underordnat eller i varje fall relaterat till denna. Varför är den så viktig, vad betyder denna lilla våg? Kanske anger den makarnas profession, att de har som huvudsyssla att räkna och väga pengar? Flera konsthistoriker har tänkt så, och därför givit målningen namnet Myntväxlaren. Men vågen kan ha en symbolisk betydelse också, något man börjar misstänka när den är så viktig att den stjäl uppmärksamheten från allt annat; den dominerar över såväl kvinnans andakt som relationen makarna emellan. För den informerade och humanistiskt bildade betraktaren skulle vågen kunna symbolisera Måttfullheten (temperantia). Både mannen och kvinnan ser onekligen måttfulla ut, som att de praktiserar denna dygd. De arbetar lugnt och systematiskt 
på sina sysslor. De förivrar sig inte och visar inga tecken på nervositet. Några prydligt upplagda pärlor, ringarna uppträdda på ett litet tygstycke och en del andra småsaker som ser exklusiva ut tyder också på att det är värderingen av sådana ting som paret ägnar sig åt i sin bod.

Vågen kan också stå som symbol för Yttersta domen, då alla själar skall vägas och värderas. Eftersom vågen ses alldeles intill bilden av Maria med Jesusbarnet ligger en sådan religiös tolkning inte allt för långt bort, trots den profana miljön $\mathrm{i}$ övrigt. På hyllorna bakom paret ligger en del böcker och ytterligare sådant som kan antas värdefullt. Dessutom ligger där ett äpple. Ett sådant oväntat inslag gör att vi gärna förstår föremålet som ett fragment. Eftersom det inte riktigt passar in i sammanhanget vill blicken gärna tolka och ge det en symbolisk betydelse. Äpplet kan i så fall vara en symbol för paradisets frukt, som Eva plockade och därmed förorsakade syndafallet. Vill målningen kanske berätta att makarna trots sin profana syssla vissa skulle kanske till och med säga yrkesmässiga girighet - har de yttersta tingen och Gus vilja i ständig åtanke? Att de är fromma fast de kan tyckas så upptagna av världsliga bestyr?

I förgrunden ses också en liten spegel av venetiansk stil. Troligen även det ett värdefullt föremål, på sin tid. I spegeln syns ytterligare en liten scen, bilden av en ensam man som sitter och läser vid ett bord. Utanför hans fönster syns ett kyrktorn. I bildens utkant, vid sidan om kvinnan, ses ytterligare en liten scen. Två personer ser ut att vara inbegripna i en livlig diskussion. En av dem höjer handen och gestikulerar ivrigt. Relationen mellan de här två scenerna 
och huvudscenen är vakanta. Betraktaren frågar sig vad de har med myntväxlandet att göra. Blicken vill inte vara med på att det finns tillfälligheter i en bild, eller att sådana här målade bilder kan vara helt osammanhängande. Men vad säger vakanserna oss då? Hur får vi ihop dem till en berättelse?

Det enda som förenar scenerna är att de visar människor inbegripna i olika aktiviteter. Huvudfigurerna känner vi redan, de är upptagna av att väga mynt. De kommunicerar inte. Scenen i förgrunden visar en man som försjunkit i en bok, kanske en religiös bok eftersom kyrktornet bakom honom är så påtagligt. Det kan kanske vara en kommentar till kvinnan, som tappat fokus i sin andaktsläsning och istället börjat betrakta mynten och vägande. Scenen i bakgrunden visar två människor i dialog. Kan den också förstås som en kommentar till huvudbilden? Paret i mellangrunden har övergivit kommunikationen med omvärlden och med varandra för att istället koncentrera sig på vägandet av pengar och värdesaker.

I relation till dessa vakanser antar målningens betydelse plötsligt ett mer kritiskt perspektiv. Den blir därmed möjligen en bild av tidig kapitalism och medföljande alienation. Istället för att fokusera på from andakt eller mänsklig interaktion har det porträtterade paret blivit till främlingar för Gud, för världen och för varandra. Vi ser inga spår av kommunikation mellan makarna utan all uppmärksamhet är riktad mot de döda tingen: vågen, mynten, pärlorna etc. Nu är betraktaren plötsligt i ett moraliskt överläge och kan fördöma paret i bilden; om det inte vore för att vi själva precis ägnat åt oss samma materialistiska och nyfikna betraktande av föremål 
och detaljer i bilden. Det är inte i första hand paret i bilden - som de facto inte är något par utan bara lite oljefärg på en duk som den performativa blicken behagar utse till ett pengafixerat par - utan betraktaren själv som har att utstå denna kritik.

På så vis kan vi åter säga, liksom i fallet med Artemisia Gentileschis målning Susanna i badet, att bilden ser tillbaka på oss. I betraktandet, i hur vi väljer att navigera bland de sakligheter som bilden ställer oss inför, måste vi nödvändigtvis involvera oss själva. Det är i hög grad våra egna fördomar och värderingar som sätts på spel i betraktandet. Kanske är den avsedda betydelsen i själva verket den motsatta: Slösa inte bort tiden med andaktsövningar och skvaller, koncentrera dig på ditt arbete istället! Den performativa blicken avslöjar oss, lär oss någonting och gör oss förhoppningsvis lite klokare.

Vilken är då skillnaden mellan ett vanligt seende och en blick? Allmänt kan sägas att seendet är mer förutsättningslöst och intresselöst, medan blicken är aktiv och skapande. Medan seendet kan vara fritt sökande och fullt av fantasier tenderar blicken att performativt skapa ordning och maktrelationer. Jacques Lacan, som betytt mycket för diskussionen om blickarnas psykologi, talade om imaginär respektive symbolisk ordning. ${ }^{9}$ Den förra är fri och kreativ, den senare bestämmande och auktoritär. Den symboliska ordningen är kategoriserande och ofta klargörande men samtidigt begränsande. Den blir aldrig fullständig utan har att leva med en rest, en tydlig brist, i förhållande till den imaginära ordningen. Blickar som söker ordning skapar samtidigt 
en brist i förhållande till verkligheten, så som vi uppfattar den mer förutsättningslöst. Det betyder inte att Lacan menade att verkligheten finns inför oss, en gång för alla given. Snarare ville han peka på att språket aldrig är tillräckligt för att fånga människans levda verklighet.

Den brist som den performativa blicken producerar i förhållande till ett mer intresselöst betraktande skall inte enbart förstås som någonting negativt. Tvärtom ger sig betraktaren in i konsten med en mer eller mindre uttalad förförståelse av att sådana brister måste få förekomma. Vi kan till och med säga att denna förlust är del av den estetiska njutningen. ${ }^{10}$ Det finns ett masochistiskt inslag i betraktandet av konst som gör att vi kan finna tillfredsställelse i en sådan underkastelse. Samtidigt som blicken söker och konstruerar maktrelationer, tvingas den till ett erkännande av sina egna tillkortakommanden.

I en målning av Santi di Tito från I 593 betyder blickarna i bilden nästan allt, så pass att bilden närmast kan sägas handla just om blickar (bild Io). ${ }^{\text {I }}$ Hela scenen verkar utspela sig i ett kyrkorum med en storslagen renässansarkitektur i klassiserande stil. I förgrunden står en man och en kvinna på knä. Mannen håller en bok framför sig och tycks läsa inför Kristus på korset. Den Korsfäste träder fram ur målningen bakom sig, som om han tillhörde den knäböjande mannens reella rum snarare än det estetiska rummet. Altartavlan bakom honom ser ut att representera ett storslaget landskap med låg horisont och mycket himmel. Kring hans huvud finns ett ljus i bilden som understryker samspelet mellan de båda representationsnivåerna. 


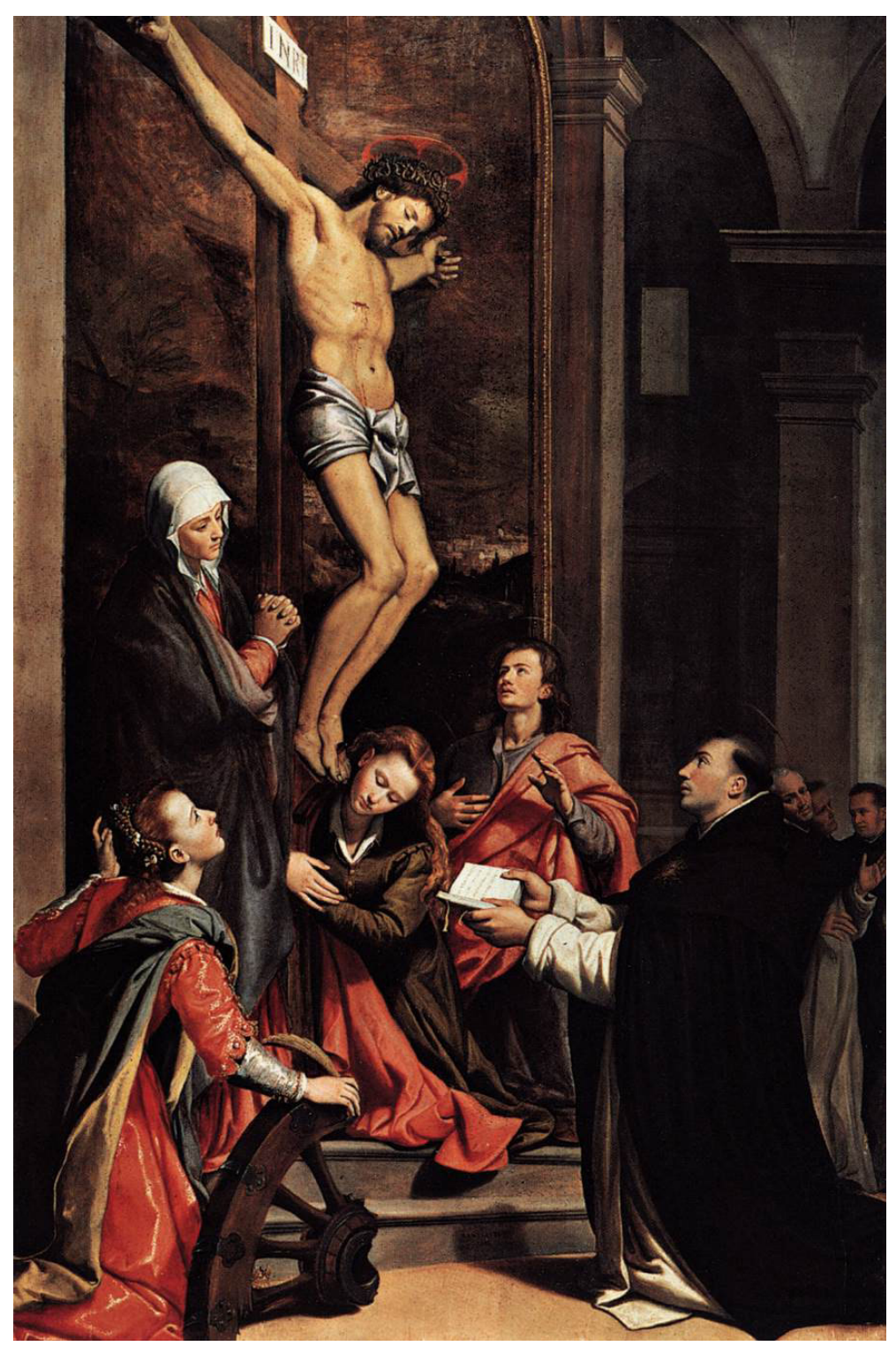

Bild 10. Santi di Tito, Korsfästelse med helgon, I 593. Olja på pannå. $362 \times 233 \mathrm{~cm}$. San Marco, Florens (Italien). Källa: Wikimedia Commons (Copyright CC-o, Public Domain) 
Efter en stunds betraktande blir vi varse att även figurerna kring korset hör till en konventionell korsfästelsescen, och inte till den bedjande mannens reella rum. Där är Maria med händerna knäppta i bön på den ena sidan korset, Johannes på den andra sidan med handen förd mot hjärtat och med blicken riktad rätt mot Kristus, samt Magdalena vid korsets fot. Hon omfamnar korset och sänker blicken sorgset. De tre fokaliserar korsfästelsen på tre olika sätt: bön, blick och beröring.

Mannen till höger tycks trots allt ha ett mer distanserat förhållande till huvudscenen. Han känner den genom läsning, genom sin bok. Det lilla formatet gör det sannolikt att det är en andaktsbok han läser. Korsfästelsescenen han står inför är i själva verket ett resultat av hans egna fromma böner; av hans förmåga att frammana det inre och göra det till någonting yttre och verkligt. Det är en performativ blick som skildras. Kristus, Maria, Johannes och Magdalena finns där tack vare mannens fromma betraktande av altartavlan. Det är hans blick som får dem att framträda och att lämna bildens rum, det estetiska rummet, för det verkliga rummet. Vid närmre betraktande upptäcker vi att mannen med boken har en tunn gloria ovanför huvudet. Inte en sådan kraftig, röd korsgloria som Kristus men dock en gloria. Han tillhör alltså inte heller vår verklighet: han är ett helgon.

Kvinnan till vänster i bild ger kanske det mest realistiska intrycket. Hon står tydligare utanför korsfästelsescenen än de andra kring korset. Hon är delvis vänd bort från betraktaren framför målningen och lyfter blicken upp mot den Korsfäste. Ena handen lyfter hon, som i häpnad inför det hon ser, 
medan den andra handen håller en fjäderpenna och fragmentet av ett hjul. För den som är bevandrad i helgonikonografin blir hon - med stegelhjulet som symbol för sitt särskilda martyrskap - till Katarina av Alexandria. Men hon tycks trots allt sakna gloria, vilket helgon brukar ha.

Längst in i bilden ses några män i en dörröppning. Från där de står kan de knappast se någonting av altarmålningen eller de bibliska gestalter som framträder. Antagligen ser de den knäböjande mannen. De lägger sina huvuden bekymrat på sned, ger varandra menande blickar och gestikulerar lite uppgivet. De saknar helt helgonattribut eller glorior, men ser möjligen prästklädda ut. Äntligen några som tillhör vår värld! En värld där bild är bild, religion är religion och vår värld är definitivt skild från allt sådant som bara är imaginärt. En värld där inte representationen blir levande och lämnar sitt avskilda rum. Men i Santi di Titos målning är denna verkliga värld tillbakaträngd och förpassad till bakgrund och marginaler. De så påtagliga, färgstarka och realistiskt skildrade fantasifigurerna tränger sig mellan oss och den reella världen. Som om den hörde till vår värld, eller var resultatet av vår egen performativa blick mot duken.

Som betraktare kan man känn ett visst obehag inför bilder av det här slaget, bilder som implicerar ett betraktande som vilar på värderingar och föreställningar som man kanske inte delar. Målningen tycks påstå att vi delar en föreställning om att bilder kan bli till verkliga uppenbarelser för oss. Att det reella och det estetiska rummet inte är avskilda utan snarare bara är beroende av vår performativa blick. Om betraktaren bara önskade skulle 
målningen kunna bli levande, precis som målningen i målningen blir. Bilden berättar om en brist i vår föreställningsvärld. Den begär att vi skall underkasta oss en symbolisk ordning som vi inte uppfattar som reell. Vår blick strävar efter makt över bilden, som i sin tur kräver underkastelse. Därför är den estetiska tillfredsställelsen av att betrakta Santi di Titos målning - antagligen för renässansens lika väl som en samtida publik - tudelad och splittrad. Det är det som gör den både skrämmande och lockande.

De bilder vi här riktat intresset mot säger oss någonting om betydelsen av den performativa blicken. Bilder blir inte till det de är utan att våra blickar riktas mot dem. Vi vore själva heller inte vad vi är, om inte konstverken mötte våra blickar och såg tillbaka på oss. Utöver att representera andra världar och värderingar kan bilder påverka och förändra vår värld och våra värderingar. Konstverk vore inte så fula och så vackra, om de aldrig blev sedda.

\section{Vidare läsning}

Peter Gillgren, Siting Federico Barocci and the Renaissance Aesthetic, Farnham $201 \mathrm{I}$.

Martin Heidegger, "... Poetically Man Dwells ...", Poetry, Language, Thought, New York 200I [I97I], s. 209-227.

Wolfgang Kemp, "The Work of Art and its Beholder. The Methodology of the Aesthetics of reception", The Subjects of Art History. Historical Objects in Contemporary Perspective, Cambridge I998, s. I80-I96.

Laura Mulvey, "Visual Pleasure and Narrative Cinema", Screen I6.3 (I975), s. 6-I 8. 
Margaret Olin, "Gaze”, Critical terms for Art History, Chicago 2003, s. 318-329.

Gaylyn Studlar, "Visual Pleasure and the Masochistic Aesthetic", Journal of Film and Video 37:2 (I985), s. 5-26.

\section{Noter}

I. Elif Shafak, The Gaze, London 2006 [I999], s. 46.

2. Se särskilt Jean Paul Sartre, Varat och intet, Stockholm I983 [I943].

3. Angående begreppen estetiskt och reellt rum, se Leo Steinberg, "Observations on the Cerasi Chapel", The Art Bulletin 4I (I959), s. I83-I90.

4. Litteraturen om Artemisia Gentileschi är synnerligen riklig. Här har jag använt fr.a. Keith Cristiansen $\&$ Judith Mann (red.), Orazio and Artemisia Gentileschi, Yale University Press 200I samt Mieke Bal (red.), The Artemisia Files, Chicago University Press, 2005.

5. Laura Mulvey, "Visual Pleasure and Narrative Cinema", Screen I6.3 (I975), s. 6-I 8.

6. Gällande de här historiska frågorna, som är mycket omdiskuterade, se Nanette Salomonsen, "Judging Artemisia. A Baroque Woman in Art History", The Artemisia Files, red. Mieke Bal, Chicago University Press, 2005, s. 38-47 (33-6I) samt vidare referenser där.

7. För en mer utförlig presentation av begreppen, se Peter Gillgren, Siting Federico Barocci and the Renaissance Aesthetic, Farnham 20I I, s. 2I-7I.

8. Gällande den här målningen och konstnärens verksamhet i övrigt, se Larry Silver, The paintings of Quinten Massys with catalogue raisonné, Oxford I984, s. I36-I 38 .

9. Jacques Lacan, "The Mirror Stage as Formative of the $I$ Function as Revealed in Psychoanalytic 
Experience", Écrits. The First Complete Edition in English, övers. Bruce Fink, New York 2006, s. 75-8I. För en genomgripande diskussion i förhållande till filmteorin, se Todd McGovan, "From the Imaginary Look to the Real Gaze", Real Gaze. Film Theory and Lacan, red. Todd McGovan, New York 2007, s. I-20. Io. Den som utvecklat dessa tankar tydligast och i kritisk dialog med Mulvey är Gaylyn Studlar. Se t ex hennes "Visual Pleasure and the Masochistic Aesthetic", Journal of Film and Video 37:2 (I985), s. 5-26.

I I. För en övergripande presentation av Santo di Tito och hans måleri, se Jack Spalding, Santi di Tito, New York I982. 